\title{
Japanese Bird-Banding Now and Past
}

\author{
Masashi Yoshii, Fumio Sato, Kiyoaki Ozaki, \\ Yoshimitsu Shigeta, Shigemoto Komeda, \\ Keiko Yoshiyasu and Amane Mitamura*
}

\begin{abstract}
This paper is described mainly for the reference of overseas banders or others who wish to know the bird-banding activities in Japan. At the beginning, the history of Japanese bird-banding is described in the three periods, the period before the War (1924-1945), the period of the Forestry Agency (1961-1971) and the period of the Anvironment Agency (1972-present). In the next part, the results of the national birdbanding shceme carried out for 1988 are abstracted and briefly described as to the numbers of birds banded, the notable banding records, the numbers of recoveries, the notable recovery records and longevity records revealed by bird-banding.
\end{abstract}

\section{Introduction}

The banding activities in Japan had ever been regularly reported in Miscellaneous Reports of Yanrashina Institute for Ornithology (MRYIO) (volume 3, number 3 to volume 9 , number 3 ) and through the reports quite a few foreign ornithologists knew the status of Japanese bird bandig at that time. After 1978, due to various reasons, the reports of banding activities in MRYIO were suspended and since then only very limited overseas ornithologists had chance to know the banding activities in Japan. In the recent trend of remarkable internationalization of ornithological activities, a good many foreigners have requested us to publish Endlish written reports on the bird banding activities in Japan. This report was made for meet such requests.

\section{History of Bird Banding in Japan}

\section{Bird Banding before the War (1924 to 1945)}

The first banding was carried out by the Wildlife Research Division of Stockbreeding Agency, Ministry of Agriculture and Commerce, in 1924, when the number of banded birds totaled 6,007 of 42 species (Uchida 1932). After this first operation, banding continued more actively, year after year, till it was suspended in 1943 because of the War. The total number of recoveries recorded up to 1944 was 15,382. Unfortunately, for 18 years during and after the War, there was no nationwide banding due to the unrest in Japanese society.

Received 28 July 1989, accepted 21 August 1989

* Bird Migration Research Center, Yamashina Institute for Ornithology, Konoyama, Abiko, Chiba, 270-11 Japan 


\section{Banding Research by the Forestry Agency (1961 to 1971)}

The International Council for Bird Preservation held its general conference in Tokyo in May 1960. At this time, the council urged in the resolution that a central organization should be set up through the joint efforts of countries in Asia and Pan Pacific regions, with the first center office in Tokyo (ICBP 1962). The Forestry Agency responsed to this resolution and decided to start banding research as a national project after the postwar intermission. They made three year financial appropriations for the project, starting in 1961. The agency's first plan was to research locations throughout the country which would be appropriate for continuous banding research in the future (Yamashina 1962, Uramoto 1962).

The 1961 research operations were conducted at 10 locations, in 7 prefectures, such as Hokkaido, Aomori, Miyagi, Chiba, Niigata, Nagano and Shizuoka. The second operation included another 10 prefectures (total 20 locations over 17 prefectures) such as Ibaragi, Kyoto, Hyogo, Tottori, Shimane, Hiroshima, Yamaguchi, Kochi, Nagasaki, and Kagoshima. In the third operation, in 1962, banding research was carried out in the 10 prefectures newly-added in the second research (Ibaragi, Hyogo, etc).

The Forestry Agency then commissioued Yamashina Institute for Ornithology to do the technical guidance, analysis of the results, and preparation of the report. After the three years of preliminary research, there was a two-year period of research suspension. Since that suspension ended, banding research has been conducted every year. However, the initial research was very poor, with little public understanding and little budget. The results from banding research was also far from satisfactory.

Circumstances improved, however, financial assistance was given by the Migratorv Animal Pathological Survey of U. S. Army (MAPS) (H. E. McClure 1974, Kuroda 1965). Also, the research was becoming more widely understood, the budget was increased, and research operations became smooth and noteworthy. This trend continued even further when the Environment Agency took over the banding research scheme from the Ministry of Agriculture and Forestry. The scale of the research has continued to grow and the results of the research have become much reliable.

\section{Banding Research by the Environment Agency (1972 to the Present)}

In 1977, the Environment Agency took over the bird banding resarch from the Ministry of Agriculture and Forestry, and changed the name of the project to the "Commissioned Project of Managing Bird Observation Stations by Environment Agency." With a ten times greater budget (from 1,439 million yen to 11,454 million yen), the Agency decided to establish long-awaited Migratory Bird Observation Stations. When the stations were put into effect, the level of banding research in Japan reached that of Western countries at long last. This decision, made by the Environment Agency, at a time when public interest in this field was very low, was considered an epoch-making decision by all concerned with banding research in Japan.

Through the steps mentioned above, the first bird observation station (Banding station) in Japan was built. First, at Fukushimagata in Niigata prefecture, in 1972, then at Hamatonbetsu, Sarobetsu and Ena, where permanent stations with accommoda- 
tion facilities were constructed.

\section{Structure of the Banding Center}

Research quickly increased at the now 60 banding stations. Accordingly, the Banding Research Division (Banding Center) of Yamashina Institute for Ornithology, reinforced the manpower for the operation of banding, accountiong, liaison work for government offices, and recording. As of 1976, the center had a complete staff 8 persons including the director.

The 60 banding stations were divided into 4 blocks, which were staffed by (1) Four block chiefs, with responsibility for the research plan budget, and other related duties; (2) One accounting staff, who took care of accountancy and general matters in connection with the Environment Agency; (3) Two recording staffs, who compile and compute records of banding or recoveries, official applications, or other government forms; and, (4) One division director, who supervised the entire banding research project. This structure has generally remained the same up until today.

\section{Banding Stations}

Thirty Banding Stations of the Environment Agency (E. A.) were set up by 1975, 10 Second-class stations were added in 1978, 10 in 1979, and 10 more stations were added by 1986 , to make the total present number of 60 stations. (10 First-class stations and 50 Second-class stations over 31 prefectures. Refer to the Fig.-1. Localities of banding stations). Among these, 8 first-class stations, except for Kunaicho Kamoba station and 2 second-class stations such as Sarobetsu and Ena, are equipped with overnight accommodation and study facilities.

Other stations, however, are not as fully equipped. Among the above mentioned 10 first class stations, Fukushimagata First-class station is the largest, with a capacity for about 15 banders. Fukushimagata station also includes a lecture room, study rooms, a storehouse, a bathroom, and a telephone, so the station is used for the annual banding workshop or study meeting, and also for joint research with foreign banders.

\section{Annual Report of Banding Research}

Only several copies of the report were previously sumitted to the Environment Agency, but since 1976, the report has been reproduced into more than 200 booklets of B-5 size $(180 \times 255 \mathrm{~mm})$ paper. If necessary for outside circulation, additional printing has also been approved.

The following outlines the contents of the annual report.

Title on the cover: REPORT OF THE BIRD MIGRATION RESEARCH CENTER

(1) Foreword

(2) Location of Banding Stations

(3) List of Banders

(4) Outline of Research

(5) Bird Banding Research

i. Summary of Bird Banding 
Table 1. Numbers of birds banded in stations.

[1988.1.1-1988.12.31]

\begin{tabular}{|c|c|c|c|c|c|c|c|}
\hline \multicolumn{2}{|r|}{ Station } & Newly & Species & Recapture & Species & Total & Species \\
\hline (1) & Hamatonbetsu & 1926 & 49 & 21 & 4 & 1947 & 49 \\
\hline 2 & Sarobetsu & 0 & 0 & 0 & 0 & 0 & 0 \\
\hline 3 & Teurijima & 630 & 14 & 57 & 1 & 687 & 14 \\
\hline 4 & Tohfutsuko & 1051 & 28 & 16 & 5 & 1067 & 28 \\
\hline 5 & Sibetsu & 2035 & 42 & 24 & 12 & 2059 & 42 \\
\hline (6) & Furenko & 6612 & 80 & 421 & 28 & 7033 & 80 \\
\hline 7 & Moyururijima & 196 & 8 & 4 & 1 & 200 & 8 \\
\hline 8 & Daikokujima & 225 & 2 & 18 & 1 & 243 & 2 \\
\hline 9 & Obihiro & 2336 & 58 & 176 & 23 & 2512 & 58 \\
\hline 10 & Tomakomai & 4939 & 84 & 163 & 27 & 5102 & 84 \\
\hline (11) & Shimokita & 1591 & 31 & 187 & 8 & 1778 & 31 \\
\hline 12 & Kabushima & 2189 & 1 & 136 & 1 & 2325 & 1 \\
\hline 13 & Takizawa & 3594 & 46 & 125 & 13 & 3719 & 46 \\
\hline 14 & Sanganjima & 282 & 5 & 166 & 3 & 448 & 5 \\
\hline 15 & Izunuma & 4565 & 41 & 362 & 16 & 4927 & 41 \\
\hline 16 & Gamou & 581 & 21 & 203 & 5 & 784 & 21 \\
\hline 17 & Hachirougata & 8 & 3 & 3 & 1 & 11 & 3 \\
\hline 18 & Tobishima & 2246 & 44 & 211 & 17 & 2457 & 44 \\
\hline 19 & Kamisu & 2480 & 38 & 559 & 13 & 3039 & 38 \\
\hline 20 & Watarasegawa & 365 & 15 & 8 & 5 & 373 & 15 \\
\hline 21 & Maebashi & 2 & 1 & 0 & 0 & 2 & 1 \\
\hline (22) & Teganuma & 94 & 27 & 9 & 6 & 103 & 27 \\
\hline (23) & Kunaichokamoba & 3403 & 12 & 2548 & 9 & 5951 & 12 \\
\hline 24 & Shinhama & 2801 & 72 & 344 & 22 & 3145 & 72 \\
\hline 25 & Sayama-Tamagawa & 3107 & 63 & 198 & 17 & 3305 & 63 \\
\hline 26 & Mikurajima & 153 & 23 & 18 & 9 & 171 & 23 \\
\hline 27 & Torishima & 136 & 4 & 1 & 1 & 137 & 4 \\
\hline 28 & Sagamigawa & 1846 & 37 & 20 & 9 & 1866 & 37 \\
\hline 29 & Awashima & 358 & 32 & 9 & 3 & 367 & 32 \\
\hline (30) & Fukushimagata & 6473 & 54 & 275 & 23 & 6748 & 54 \\
\hline 31 & Kashiwazaki & 885 & 20 & 2 & 1 & 887 & 20 \\
\hline (32) & Fuchu & 2910 & 49 & 39 & 17 & 2949 & 49 \\
\hline 33 & Hegurajima & 1436 & 62 & 110 & 18 & 1546 & 62 \\
\hline 34 & Kahokugata & 1498 & 71 & 57 & 15 & 1555 & 71 \\
\hline (35) & Otayama & 1888 & 40 & 24 & 10 & 1912 & 40 \\
\hline 36 & Yamanakako & 135 & 22 & 38 & 12 & 173 & 22 \\
\hline 37 & Chikumagawa & 2142 & 56 & 257 & 17 & 2399 & 56 \\
\hline 38 & Karuizawa & 80 & 19 & 19 & 6 & 99 & 19 \\
\hline 39 & Matsumoto & 4921 & 82 & 122 & 24 & 5043 & 82 \\
\hline 40 & Ena & 0 & 0 & 0 & 0 & 0 & 0 \\
\hline 41 & Shizuoka & 726 & 33 & 184 & 7 & 910 & 33 \\
\hline 42 & Nabeta & 1037 & 38 & 121 & 16 & 1158 & 38 \\
\hline 43 & Okazaki & 3962 & 71 & 448 & 26 & 4410 & 71 \\
\hline 44 & Kanmurijima & 1111 & 4 & 879 & 1 & 1990 & 4 \\
\hline 45 & Ujigawa & 3537 & 72 & 361 & 31 & 3898 & 72 \\
\hline 46 & Yodogawaguchi & 165 & 12 & 9 & 2 & 174 & 12 \\
\hline 47 & Nakaumi & 6 & 5 & 0 & 0 & 6 & 5 \\
\hline
\end{tabular}




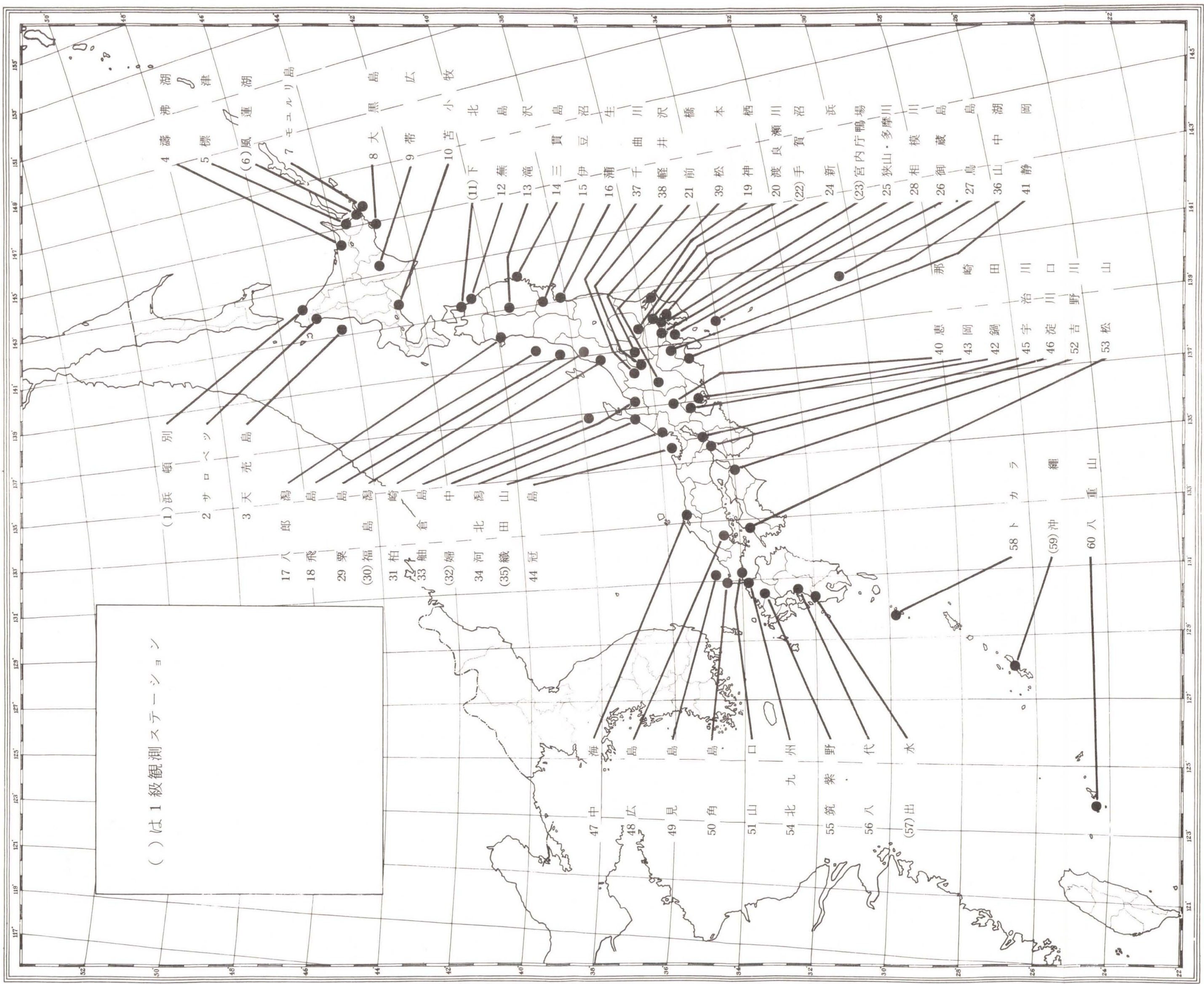

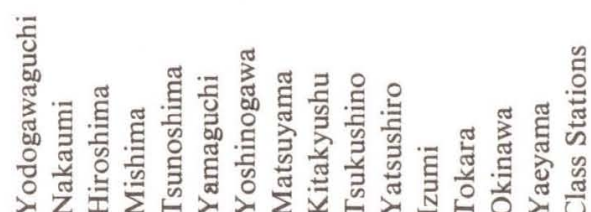

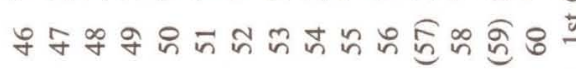

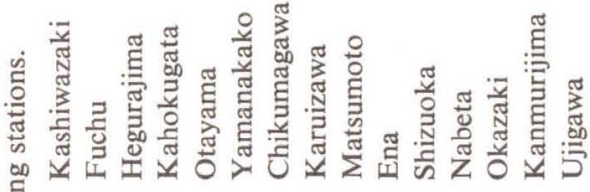

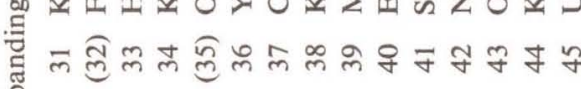

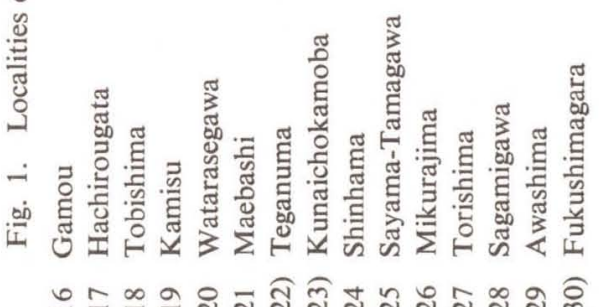

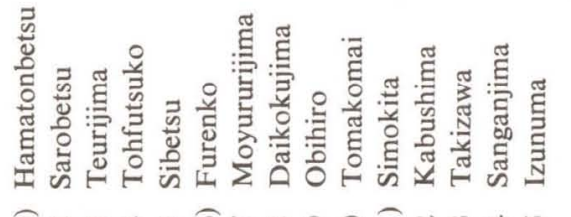

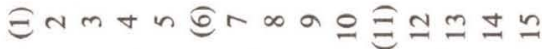


Table 1. Continued

\begin{tabular}{clrrrrrr}
\hline & Station & Newly & Species & Recapture & Species & Total & Species \\
\hline 48 & Hiroshima & 1149 & 49 & 176 & 18 & 1325 & 49 \\
49 & Mishima & 150 & 22 & 8 & 4 & 158 & 22 \\
50 & Tsunoshima & 69 & 17 & 1 & 1 & 70 & 17 \\
51 & Yamaguchi & 8927 & 93 & 557 & 31 & 9484 & 93 \\
52 & Yoshinogawa & 104 & 21 & 7 & 5 & 111 & 21 \\
53 & Matsuyama & 51 & 12 & 2 & 2 & 53 & 12 \\
54 & Kitakyushu & 3470 & 82 & 251 & 20 & 3721 & 82 \\
55 & Tsukushino & 3008 & 71 & 240 & 22 & 3248 & 71 \\
56 & Yatsushiro & 1457 & 45 & 33 & 7 & 1490 & 45 \\
$(57)$ & Izumi & 428 & 30 & 29 & 10 & 457 & 30 \\
58 & Tokara & 194 & 30 & 63 & 15 & 257 & 30 \\
$(59)$ & Okinawa & 1456 & 8 & 91 & 2 & 1547 & 8 \\
60 & Yaeyama & 904 & 20 & 173 & 6 & 1077 & 20 \\
61 & Others & 16551 & 164 & 1135 & 64 & 17686 & 164 \\
\hline
\end{tabular}

( ): 1st class station

ii. Birds Newly Banded

iii. Number of Birds Recaptured at Banding Stations

iv. Notable Banding Records

(6) Recoveries

i. Summary of Recoveries

ii. Signs and Abbreviations

iii. Recovery Report (in Japanese and English with longitudes and latitudes)

iv. Notable Recoveries

v. Longevity Records

\section{Ecological Research in Banding Areas}

The above mentioned format has been used since 1976, with the article of "Swan Collar-marking" being added in 1977, "Geese Collar-mavking" in 1982 and Crane Banding in 1988. These annual reports have been referred to by many ornithologists and bird protection-related organizations as the most important and reliable data on bird distribution and migration in Japan. There is a high demand for this report even among the ornithologists overseas.

\section{Bird Banding in 1988}

Our Bird Migration Research Center, Yamashina Institute for Ornithology, commissioned by the Environment Agency, carried out the national bird banding project for 1988. The details of banding activities were published in form of an annual report with the title of "Report of the Bird Migration Research Center", which was written in Japanese. The following is a condensed version of the report. All the information was obtained in 1988. 


\section{Numbers of Birds Banded for 1988}

The totals of banded birds were taken from the list of the birds banded for the period 1 January to 31 December 1988, except the numbers of ducks banded at Kunaichokamoba (the Imperial Duck Refuges) during the wintering period of 1987/1988. During the report year, 120, 581 birds of 285 species were newly banded, 14, 418 birds more than the number banded in the preceding year. Previously banded 11,718 birds of 148 species were recaptured. See Table 1.

Of the totals of the banded birds, roughly $15 \%$ are non-passerine birds and $85 \%$ are passerines.

Five species of higher rank of the banded birds are:

$\begin{array}{lrc}\text { Black-faced Bunting Emberiza spodocephala } & 23,555 & \text { birds } \\ \text { Reed Bunting Emberiza schoeniculus } & 14,194 & \text { " } \\ \text { Rustic Bunting Emberiza rustica } & 9,968 & \text { " } \\ \text { House Swallow Hirundo rustica } & 8,814 & \text { " } \\ \text { Tree Sparrow Passer montanus } & 4,505 & \text { " }\end{array}$

All of the above mentioned birds are massively caught in the reedbed fields. The the five species together there are more than 60,000 birds, more than $50 \%$ of the grand total of the birds banded during the report year.

\section{Notable Banding Records}

Out of 285 species banded for the report year, the following five species are the newest banding records in Japan since 1961.

(a) Japanese Crane Grus japonensis (band no. 150-0601, T01. and 150-0602, T02)

For a long time peculiar local conditions had made the banding of this species remain a strict taboo and that was an obstacle in the study of behaviours of this species and promoting proper measures for preservation. Since several years ago such taboo has been eased and we were able to band this species. A young crane (T01) about 4 weeks old and another (T02) 6 weeks old crane were caught and banded respectively on July 9 and July 11, 1988 at the wetland in Nemuro City, eastern Hokkaido. On November 9, T01 was found dead under a high-voltage cable. This bird was supposed to have crashed against the cable. T02 was observed healthy with its parents on and after November 18 at Tsurui Village about $117 \mathrm{~km}$ east of the place where originally banded.

(b) Pectoral Sandpiper Calidris melanotos (band no. 040-29414) Very rare transient species in Japan. Mr. T. Maeda banded one bird at Kobe, Hyogo-ken on Oct. 1, 1988. First banding record in Japan.

Measurements: Wing $124.7 \mathrm{~mm}$. Tail $53.0 \mathrm{~mm}$. Tarsus $26.5 \mathrm{~mm}$. Culmən $29.2 \mathrm{~mm}$. Weight $76 \mathrm{~g}$. Sex unknown. Age unknown.

(c) Dusky Warbler Philloscopus fuscatus (band no. 026-06824)

This species had never been offially recorded in Japan before a bird was caught at the banding site of Mishima, Yamaguchi-ken in 1984. The bird was then measured and photographed but not identified to be this species. The bird was released without banding. Later, it was determinded to be this species and became the first record in 
Table 2. Numbers of recoveries (1, Jan. 1988 31. Dec. 1988)

\begin{tabular}{|c|c|c|c|c|c|}
\hline & Species & $\begin{array}{c}\text { Domestric } \\
\text { Rc. }\end{array}$ & Foreign & Rc. banded & Total \\
\hline 1 & Calonectris leucomelas & 2 & 1 & & 3 \\
\hline 2 & Sula leucogaster & 1 & 4 & & 5 \\
\hline 3 & Phalacrocorax carbo & 4 & & & 4 \\
\hline 4 & Nycticorax nycticorax & 4 & & & 4 \\
\hline 5 & Bubulcus ibis & 1 & & & 1 \\
\hline 6 & Egretta intermedia & & 1 & & 1 \\
\hline 7 & Egretta garzetta & 2 & & & 2 \\
\hline 8 & Branta canadensis & 5 & & & 5 \\
\hline 9 & Cygnus olor & 1 & & & 1 \\
\hline 10 & Cygnus cyguns & 1 & 1 & & 2 \\
\hline 11 & Anas platyrhynchos & 9 & 13 & & 22 \\
\hline 12 & Anas poecilorhyncha & 3 & & & 3 \\
\hline 13 & Anas crecca & 1 & 1 & & 2 \\
\hline 14 & Anas penelope & 5 & 15 & & 20 \\
\hline 15 & Anas acuta & 205 & 109 & & 314 \\
\hline 16 & Anas clypeata & 1 & 5 & & 6 \\
\hline 17 & Aythya fuligula & & 1 & & 1 \\
\hline 18 & Aythya marila & & 1 & & 1 \\
\hline 19 & Milvus migrans & 1 & & & 1 \\
\hline 20 & Haliaeetus albicilla & 1 & & & 1 \\
\hline 21 & Accipiter gentilis & 1 & & & 1 \\
\hline 22 & Butastur indicus & 1 & & & 1 \\
\hline 23 & Grus japonensis & 1 & & & 1 \\
\hline 24 & Charadrius mongolus & & 1 & & 1 \\
\hline 25 & Xenus cinereus & & 2 & & 2 \\
\hline 26 & Gallinago hardwickii & & 1 & & 1 \\
\hline 27 & Larus ridibundus & & & 1 & 1 \\
\hline 28 & Larus schistisagus & 3 & & & 3 \\
\hline 29 & Larus crassirostris & 12 & 1 & & 13 \\
\hline 30 & Sterna dougallii & 37 & & & 37 \\
\hline 31 & Sterna albifrons & 24 & & & 24 \\
\hline 32 & Cerorhinca monocerata & 22 & & & 22 \\
\hline 33 & Strix uralensis & 1 & & & 1 \\
\hline 34 & Apus affinis & 1 & & & 1 \\
\hline 35 & Hirundo rustica & 13 & 1 & 1 & 15 \\
\hline 36 & Motacilla cinerea & 1 & & & 1 \\
\hline 37 & Motacilla alba & 8 & & & 8 \\
\hline 38 & Cinclus pallasii & 2 & & & 2 \\
\hline 39 & Erithacus calliope & 1 & & & 1 \\
\hline 40 & Phenicurus auroreus & 1 & & & 1 \\
\hline 41 & Turdus dauma & 1 & & & 1 \\
\hline 42 & Turdus cardis & 2 & & & 2 \\
\hline 43 & Turdus chrysolaus & 5 & & & 5 \\
\hline 44 & Turdus pallidus & 1 & & & 1 \\
\hline 45 & Turdus naumanni & 2 & 1 & & 3 \\
\hline 46 & Cettia diphone & 2 & & & 2 \\
\hline 47 & Acrocephalus bistrigiceps & 2 & & & 2 \\
\hline
\end{tabular}


Table 2. Continued

\begin{tabular}{llrrr}
\hline \hline \multicolumn{1}{c}{ Species } & $\begin{array}{c}\text { Domestric } \\
\text { Rc. }\end{array}$ & $\begin{array}{c}\text { Foreign } \\
\text { Rc. }\end{array}$ & $\begin{array}{c}\text { Rc. banded } \\
\text { Abroad }\end{array}$ & Total \\
\hline 48 & Acrocephalus arundinaceus & 2 & & 2 \\
49 & Phylloscopus occipitalis & 1 & & 1 \\
50 & Remiz pendulinus & 10 & & 10 \\
51 & Parus major & 4 & & 4 \\
52 & Zosterops japonica & 2 & & 2 \\
53 & Emberiza yessoensis & 1 & & 1 \\
54 & Emberiza rustica & 9 & & 9 \\
55 & Emberiza spodocephala & 50 & & 50 \\
56 & Emberiza schoeniclus & 187 & & 188 \\
57 & Carduelis sinica & 1 & & 1 \\
58 & Uragus sibiricus & 2 & & 2 \\
59 & Passer montanus & 4 & & 4 \\
60 & Sturnus cineraceus & 5 & & 5 \\
61 & Corvus macrorhynchos & 22 & & \\
\hline
\end{tabular}

Japan. During the report year, one bird was banded by the banding team of Yamashina Institute at Hegurajima, Ishikawa-ken on 26 April. The first time for this species. Measurements: Length $130 \mathrm{~mm}$. Wing (natural curve) $59 \mathrm{~mm}$. Tail $51 \mathrm{~mm}$. Culmen $8.2 \mathrm{~mm}$. Tarsus $22.4 \mathrm{~mm}$. Wingspan $185 \mathrm{~mm}$. Weight $10.5 \mathrm{~g}$.

(d) Pallas's Willow Warbler Phylloscopus proregulus (band no. 010-18601)

Very rare species in Japan. Mr. J. Miura banded one indivisual on September 24, 1988 at Shimamaki-gun (510 $\mathrm{m}$ above sea level), southern Hokkaido. He later banded another bird on October 4 at Tomakomai City, S. Hokkaido (010-18604). Both were juvenile birds and the sex unknown.

$\begin{array}{cccccccc} & \text { Length } & \text { Wing } & \text { Tail } & \text { Tarsus } & \text { Culmen Wingspan } & \text { Weight } \\ & \mathrm{mm} & \mathrm{mm} & \mathrm{mm} & \mathrm{mm} & \mathrm{mm} & \mathrm{mm} & \mathrm{g} \\ 010-18601 & 9.5 & 51.2 & 41.0 & 15.2 & 7.5 & 124 & 6.5 \\ 010-18604 & 10.0 & 48.8 & 41.8 & 18.6 & 9.7 & 118 & 6.2\end{array}$

(e) Black-headed Bunting Emberiza melanocephala (band no. 2B-03634)

Only two were recorded in Japan (Ornithological Society of Japan 1974, CheckList of Japanese Birds). Because of its distribution far from Japan, there was a possibility that they might be escapee from cages, but there is no evidence to clear the suspicion. An adult female was banded by Mr. N. Kondo on October 19, 1988 at Nemuro City, eastern Hokkaido. It is the first banding record of this species in Japan.

Measurements: Length $152 \mathrm{~mm}$. Wing $82.5 \mathrm{~mm}$. Tail $66.2 \mathrm{~mm}$. Tarsus $21.3 \mathrm{~mm}$. Culmen $12.3 \mathrm{~mm}$. Weight not measured.

\section{Numbers of Recoveries of Banded Birds}

During the period of report year, 853 recoveries of 61 species were reported to our Bird Migration Research Center. Table 2 shows the recoveries in three categories 
i. birds banded and recovered in Japan, ii. birds banded in Japan and recovered in foreign area and iii. birds banded abroad and recovered in Japan.

\section{Notable Recovery Records}

(a) Intermediate Egret Egretta intermedia (band no. 100-33189, Fig. 2)

In regard to the bandedbirds of this species, so far 31 recovereies were reported from the Philippines but never from the mainland China. The following report was obtained from China for the first time.

Banded: May 30, 1985. Kumage-gun, Yamaguchi-ken $\left(33^{\circ} 57^{\prime} \mathrm{N} 132^{\circ} 06^{\prime} \mathrm{E}\right)$ Sex unknown. Age pullus. Banded by Mr. S. Kobayashi.

Recovered: March 20, 1987. Chongming Dao in the mouth of Changkiang River, Shanghai, China $\left(31^{\circ} 36^{\prime} \mathrm{N} 121^{\circ} 18^{\prime} \mathrm{E}\right)$

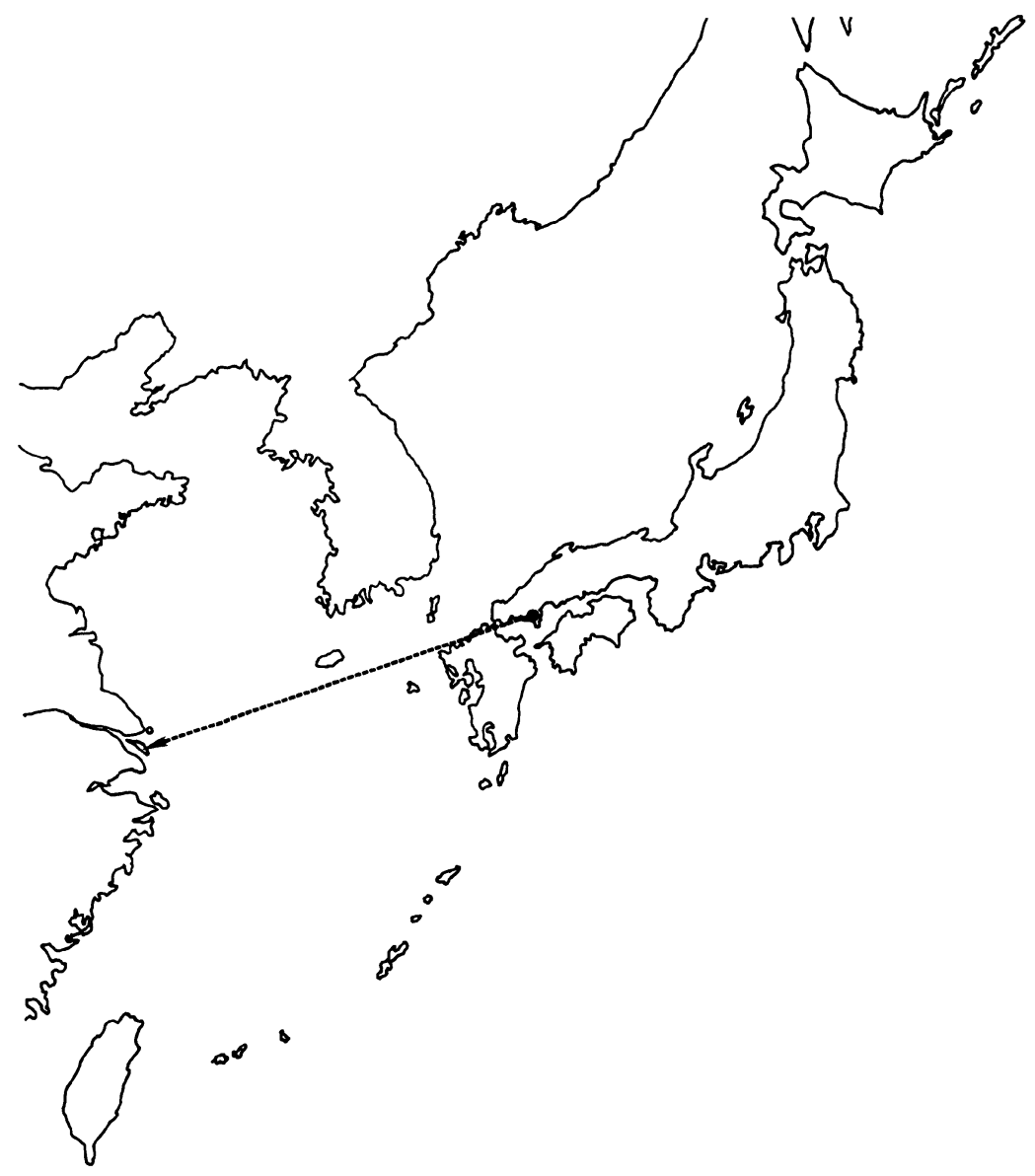

Fig. 2. Egretta intermedia.

- Yamaguchi-ken 30. 5. '85 UP

$\ldots \rightarrow$ Shanghai, China 20. 3. '87 UU 




Fig. 3. Charadrius mongolus.

- Miyagi-ken 8. 9. '74 UA

....) Shanghai, China 0. 5. '85 UU

(b) Mongolian Plover Charadrius mongolus (band no. 030-03237, Fig. 3)

Priviously we had a recoverey report of this species from Yingkou, Liaoning Province of mainland China. During the period of report year the following second recovery was reported from China. Both plovers were banded at Gamou by same bander.

Banded: September 8, 1974. Gamou, Miyagi-ken $\left(38^{\circ} 15^{\prime} \mathrm{N} 141^{\circ} 01^{\prime}\right)$ Banded by Mr. K. Takemaru.

Recovered: Unknown date of May 1985. Chongming Dao, Shanghai, China $\left(31^{\circ}\right.$ $\left.36^{\prime} \mathrm{N} 121^{\circ} 18^{\prime} \mathrm{E}\right)$. 


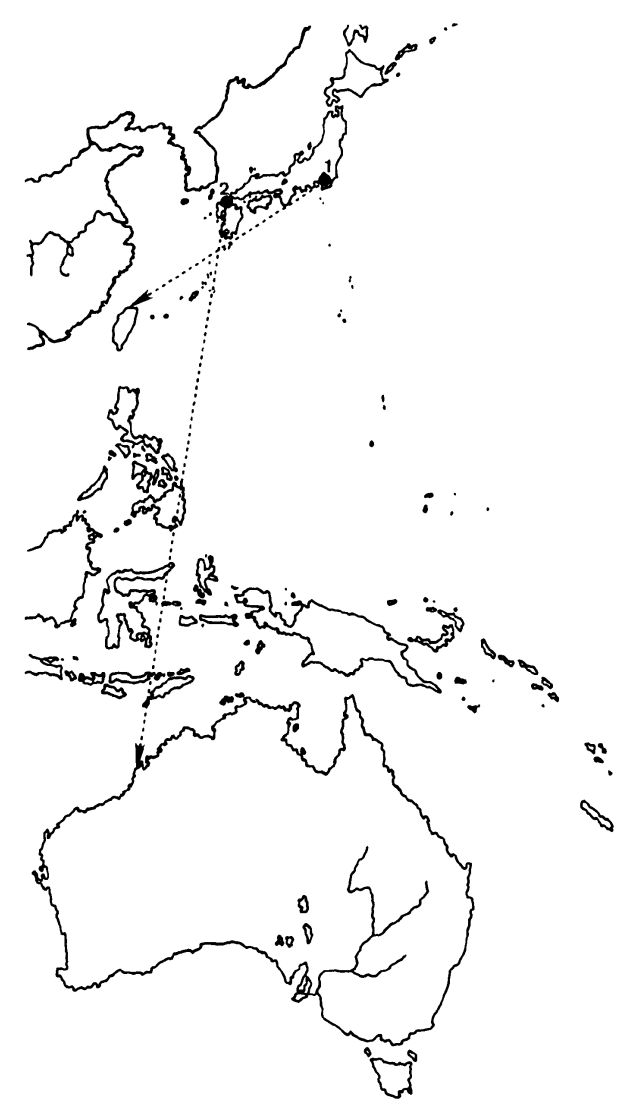

Fig. 4. Xenus cinereus.

- 1 Chiba-ken 5. 9. '86 UJ

.... Taipei, Taiwan 24. 4. '88 UA

2 Fukuoka-ken 18. 5. '83 UA

.... Broom, Australia 24. 3. '88 UU

(c) Terek Sandpiper Xenus cinereus (band no. 040-24823. 050-18682, Fig. 4) The following two recoveries were reported from Taiwan and Australia.

040-24823 Banded: September 5, 1986. Mouth of Obitsu River, Kisarazu, Chiba-ken $\left(35^{\circ} 25^{\prime} \mathrm{N} 139^{\circ} 54^{\prime} \mathrm{E}\right)$. Sex unknown. Age juvenile. Banded by Mr. Y. Shigeta.

Recovered: April 24, 1988. Kuanto Nature Reserve, Taipei, Taiwan $\left(25^{\circ} 07^{\prime} \mathrm{N} 121^{\circ}\right.$ $00^{\prime}$ E). Recovered by Taipei Bird-Watching Society.

050-18682 Banded: May 18, 1983. Kitakyushu, Fukuoka-ken $\left(33^{\circ} 49^{\prime} \mathrm{N} 130^{\circ} 58^{\prime} \mathrm{E}\right)$.

Sex unknown. Age adult. Banded by Mr. M. Takeshita.

Recovered: March 24, 1988. Roebuck Bay, Broome, Western Australia, Australia $\left(18^{\circ} 00^{\prime} \mathrm{S} 122^{\circ} 22^{\prime} \mathrm{E}\right)$ 




Fig. 5. Gallinago hardwickii.

- Hokkaido 7. 6. '85 UA

.... King I. Australia 4. 1. '88 UU

(d) Latham's Snipe Gallinago hardwickii (band no. 060-89313, Fig. 5)

The recoveries of this species in the past were from eastern part of Australian continent. The following recovery is the first one from the outside of the continent.

Banded: June 7, 1985. Shiranuka-machi, Shiranuka-gun, Hokkaido (42 $57^{\prime} \mathrm{N} 144^{\circ}$ $05^{\prime}$ E). Sex unknown. Age adult. Banded by Mr. M. Umemoto.

Recovered: January 4, 1988 . Yellow Rock Beach, King Island, Tasmania, Australia $\left(39^{\circ} 41^{\prime} \mathrm{S} 143^{\circ} 55^{\prime} \mathrm{E}\right)$. 


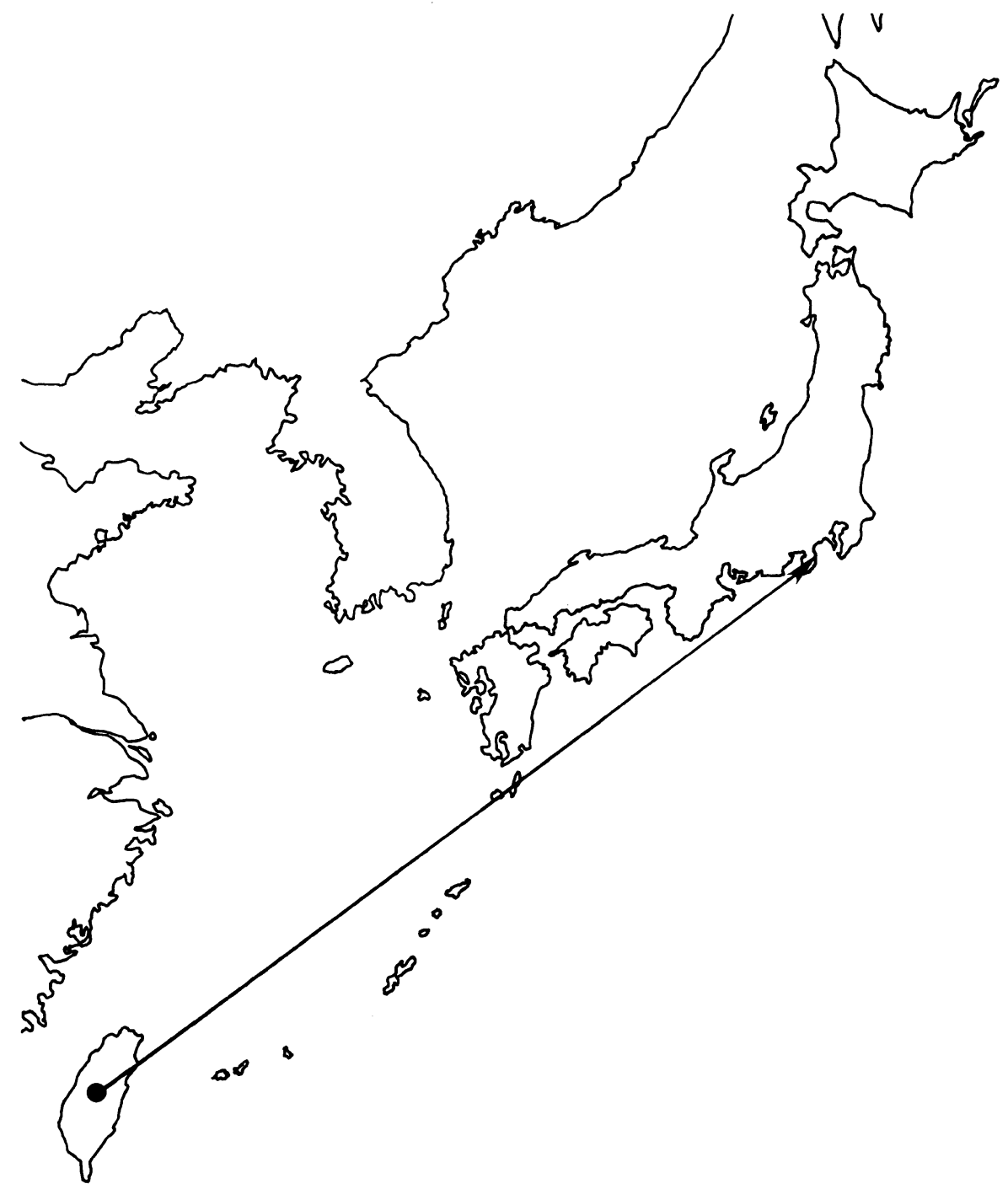

Fig. 6. Hirundo rustica.

Nanto Hsien, Taiwan 9. 4. '88 UU

$\rightarrow$ Shizuoka-ken 29. 4. '88 우 U

(e) House Swallow Hirundo rustica (BOX30 Taipei 00245, Fig. 6)

The following recovery that a swallow banded in Taiwan was recovered in Japan is the first one after the MAPS project finished (McClure 1974).

Banded: April 9, 1988. Nanto Prefecture, Taiwan $\left(23^{\circ} 59^{\prime} \mathrm{N} 120^{\circ} 59^{\prime} \mathrm{E}\right)$. Sex unknown. Age unknown.

Recovered: April 29, 1988 . Tomido, Ito City, Shizuoka-ken $\left(34^{\circ} 55^{\prime} \mathrm{N} 139^{\circ} 07^{\prime}\right)$. Sex female. Age unknown. 


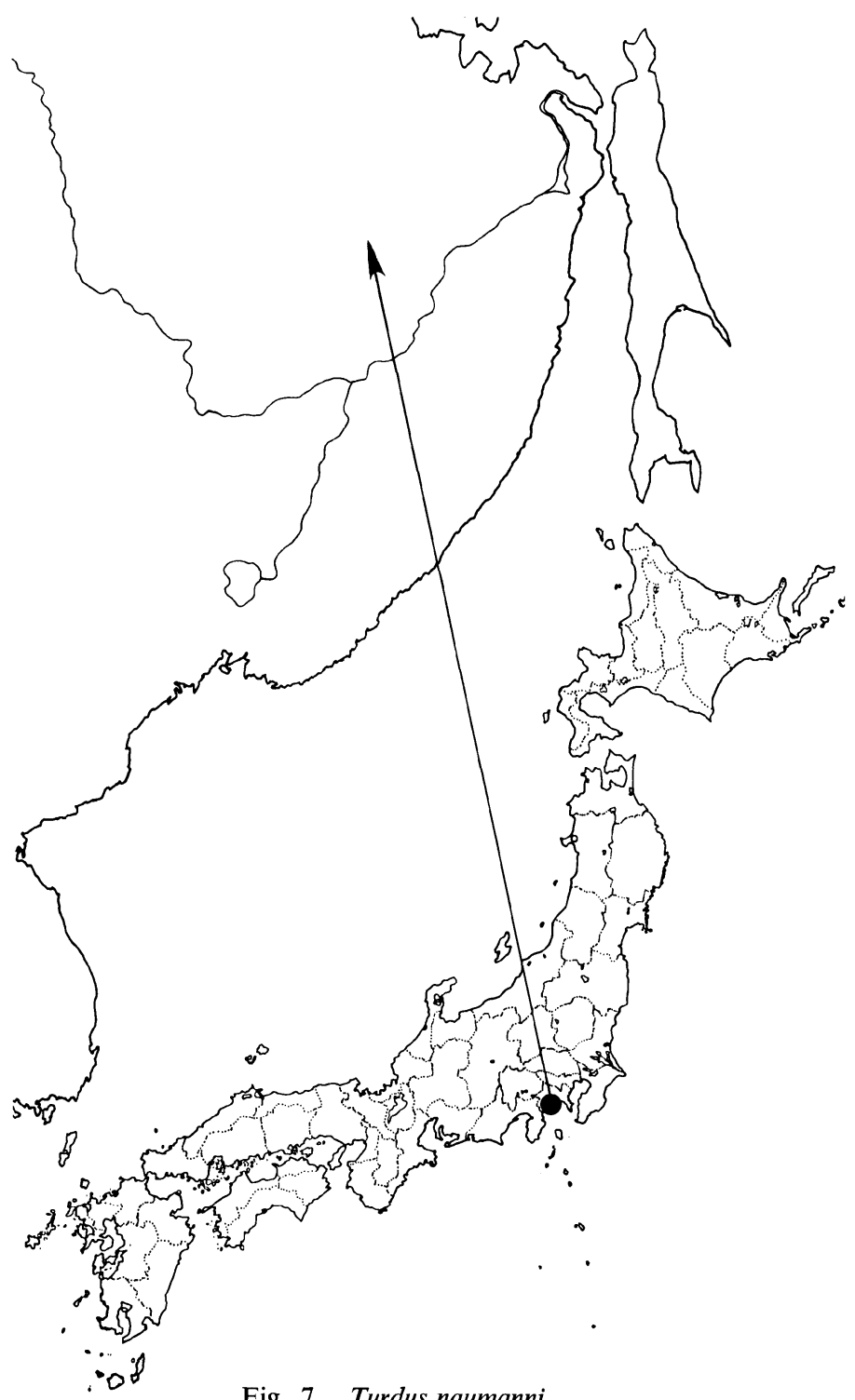

Fig. 7. Turdus naumanni.

- Kanagawa-ken 26. 1. '86 UA

$\rightarrow$ Khabarovsk, USSR 24. 5. '86 UV

(f) Dusky Thrush Turdus naumanni (band no. 040-30762, Fig. 7)

This is the second record from USSR after the very old record of a dusky thrush recovered at Sakhaline (Kuroda 1954).

Banded: January 26, 1986. Sakawagawa, Odawara-shi, Shizuoka-ken $\left(35^{\circ} 16^{\prime} \mathrm{N}\right.$ $\left.139^{\circ} 10^{\prime} \mathrm{E}\right)$. Sex unknown. Age adult.

Recovered: May 24, 1986. Solnechny vil., Komsomolysky reg., Khabarovsk, USSR $\left(50^{\circ} 43^{\prime} \mathrm{N} 136^{\circ} 38^{\prime} \mathrm{E}\right)$. 


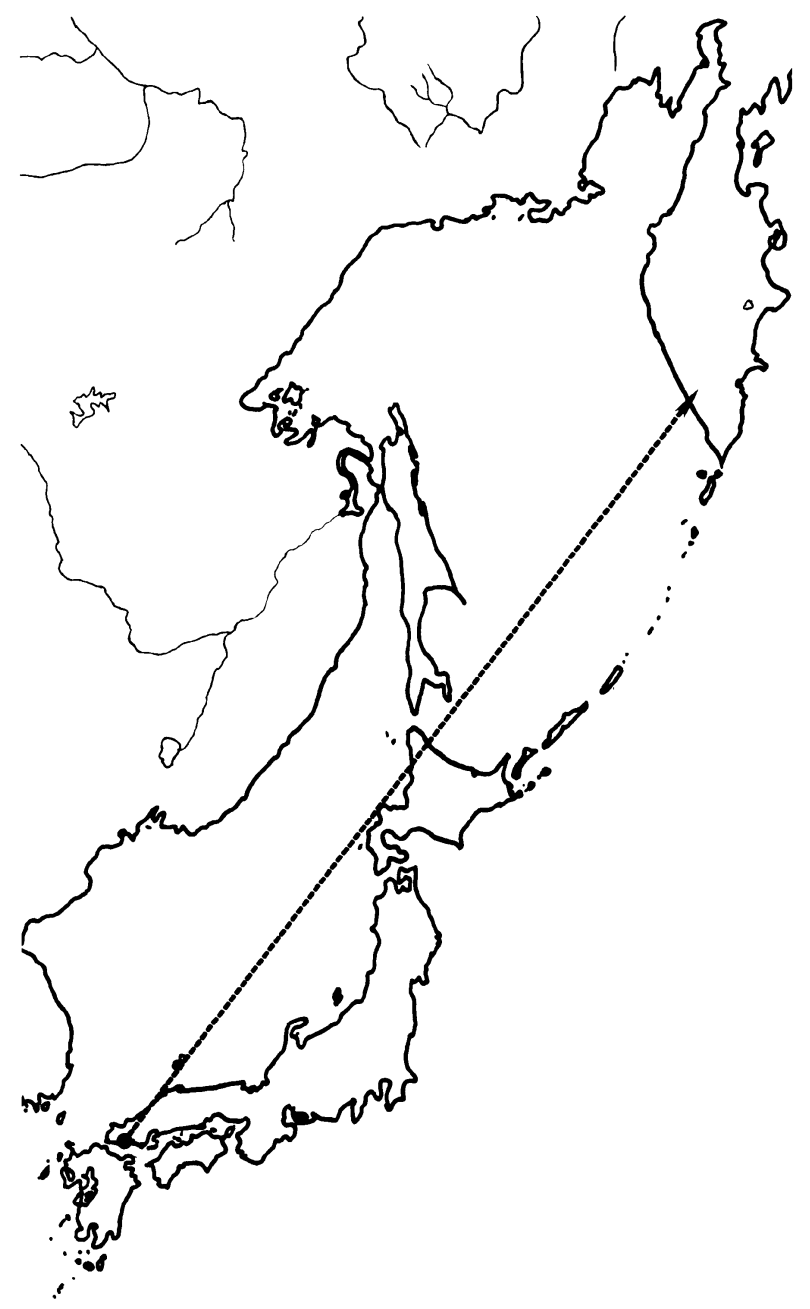

Fig. 8. Emberiza schoeniclus.

- Yamaguchi-ken 21. 11. '84 ô A

.... Kamchatka, USSR 28. 5. '87 o A

(g) Reed Bunting Emberiza schoeniclus (band no. 024-48452, Fig. 8)

Banded: November 21, 1984. Nishinoura, Hofu-shi, Yamaguchi-ken $\left(34^{\circ} 02^{\prime} \mathrm{N} 131^{\circ}\right.$ $30^{\prime}$ E). Sex male. Age adult.

Recovered: May 28, 1987 . Ust Bolsheretsk reg. Kamchatka, USSR $\left(52^{\circ} 20^{\prime} \mathrm{N} 156^{\circ}\right.$ $27^{\prime} \mathrm{E}$ ). 
Table 3. Longevity records I

\begin{tabular}{llc}
\hline \hline \multicolumn{1}{c}{ Species } & & (Years-Months) \\
\hline Streaked Shearwater & Calorectris leucomelas & $(17-02)$ \\
Madeiran Fork-tailed Petrel & Oceanodroma castro & $(12-01)$ \\
Brown Booby & Sula leucogaster & $(11-02)$ \\
Whooper Swan & Cygnus cygnus & $(08-06)$ \\
Mallard & platyrhynchos & $(12-09)$ \\
Spotbill Duck & Anas Anas poecilorhyncha & $(07-11)$ \\
Pintail & Anas acuta & $(14-01)$ \\
Mongolian Plover & Charadrius mongolus & $(10-07)$ \\
Dunlin & Calidris alpina & $(05-11)$ \\
Slaty-backed Gull & Larus schistisagus & $(11-11)$ \\
Black-tailed Gull & Larus crassirostris & $(14-11)$ \\
Bridled Tern & Sterna anaethetus & $(07-02)$ \\
Common Noddy & Anous stolidus & $(11-02)$ \\
Hornbilled Puffin & Cerorhinca monocerata & $(14-11)$ \\
House Swift & Apus affinis & $(06-10)$ \\
House Swallow & Hirundo rustica & $(07-01)$ \\
Rustic Bunting & Emberiza rustica & $(06-07)$ \\
\hline
\end{tabular}

Table 4. Longevity records II

\begin{tabular}{llc}
\hline \multicolumn{1}{c}{ Species } & & (Years-Months) \\
\hline Leach's Forktailed Petrel & Oceanodroma leucomelas & $(13-11)$ \\
Short-tailed Albatross & Diomedea albatrus & $(17-07)$ \\
Common Cormorant & Phalacrocorax carbo & $(11-07)$ \\
Night Heron & Nycticorax nycticorax & $(11-06)$ \\
Intermediate Egret & Egretta intermedia & $(13-02)$ \\
Little Egret & Egretta garzetta & $(12-01)$ \\
Wigeon & Anas penelope & $(10-03)$ \\
Turnstone & Arenaria interpres & $(12-09)$ \\
South Polar Skua & Catharacta maccormicki & $(17-07)$ \\
Black-tailed Gull & Larus crassirostris & $(14-11)$ \\
RoseaTE Tern & Sterna dougallii & $(10-11)$ \\
Sooty Tern & Sterna fuscata & $(22-02)$ \\
Little Tern & Sterna Albifrons & $(13-00)$ \\
Scops Owl & Otus scops & $(14-01)$ \\
House Martin & Delichon urbica & $(08-11)$ \\
White Wagtail & Motacilla alba & $(09-01)$ \\
Bull-headed Shrike & Lanius bucephalus & $(06-09)$ \\
Dusky Thrush & Turdus naumanni & $(09-10)$ \\
Black-browed Reed Wabler & Acrocephalus bistrigiceps & $(06-03)$ \\
Great Reed Wabler & Acrocephalus arundinaceus & $(11-00)$ \\
Japanese White-eye & Zosterops japonica & $(06-11)$ \\
Black-faced Bunting & Emberiza spodocephara & $(08-02)$ \\
Reed Bunting & Emberiza schoeniclus & $(09-02)$ \\
Grey Starling & Sturnus cineraceus & $(06-11)$ \\
Jay & Garrulus glandarius & $(06-01)$ \\
\hline
\end{tabular}


Although 706 domestic recoeries of this species were reported in the past but never from abroad. This is the first overseas recorery that was reported by Dr. Gerasimov, a Russian ornithologist, who recently began bird banding of small birds. together with his main study of geese.

\section{Longevity Records Revealed by Banding Data}

During the period of report year, following new longevity records were obtained (Table 3).

Exclusive from the above mentioned but notable longevity records previously obtained in Japan are shown in Table 4.

\section{References}

Kuroda, N. 1954. Eine kurze Übersicht über Vogelberingung in Japan. Vogelwarte 17(3): 201-205. Kuroda, N. 1965. A note on Japanese Bird-ringing tody. Ring 42: 103-104.

McClure, H. E. 1974. Migration and Survival of the Birds of Asia. Bangkok, Thailand. 476 pp.

Uchida, S. 1932. Studies of Swallows by the banding method. Bird-banding 3(1): 1-11.

Uramoto, M. 1962. 1st annual report on the bird-ringing scheme for the year ending 31st March 1962. Mis. Rep. Yamashina Inst. Orn. 3(3): 138-143.

Yamashina, Y. 1962. On the new scheme of bird-banding in Japan. Mis. Rep. Yamashina Inst. Orn. 3(3): 135-137.

\section{日本の鳥類標識調查の過去と現在}

本報告は外国の鳥類標識調查関係者に対して，日本における標識調査の大要を紹介することを主な目的 として作成した。

はじめに, 日本の標識調査の歴史について, 戦前 (1924 1945), 戦後林野庁が行なった時期 (1961〜 1971)，環境庁が実施した時期（1972～1988）の期に分けて，調査の概要を述べた。

次に, 昨年度 (1988 年度) の調査結果のらち, 標識放鳥個体数 (鳥種数も含む), 注目に価する標識例, 鳥種別回収数, 注目に価する回収例, ならびに，標識鳥の寿命の記録について述べた。

吉井 正, 佐藤文男, 尾崎清明, 茂田良光, 米田重玄, 吉安京子, 三田村あ交站：山階鳥類研究所標識 研究室 270-11 我孫子市高野山 